\title{
PRIORITY EFFECTS IN CORAL REEF FISH COMMUNITIES OF THE GREAT BARRIER REEF
}

\author{
Glenn R. Almany ${ }^{1}$ \\ Department of Zoology, Oregon State University, Corvallis, Oregon 97331-2914 USA
}

\begin{abstract}
Priority effects occur when established residents influence the colonization of individuals entering the community and thus provide insight into mechanisms underlying spatial differences and temporal changes in community composition. Using 20 spatially isolated patch reefs, I factorially manipulated the presence and absence of resident predators (groupers and dottybacks) and potential competitors (damselfishes) to determine whether and how they affect subsequent recruitment and mortality of newly settled fishes. During the 50-day experiment at Lizard Island (Great Barrier Reef, western Pacific), prior residency by predators dramatically reduced recruitment of damselfish, surgeonfish, butterflyfish, and rabbitfish and increased damselfish recruit mortality. In contrast, prior residency by potential competitors only reduced recruitment of damselfish and rabbitfish and did not affect recruit mortality. Effects of competitors were likely due to aggressive interactions between competitors and recruits that increased susceptibility of recruits to predators. Effects of residents were strongest within 48 hours of settlement, resulting in rapid establishment of patterns that persisted to the conclusion of the experiment. These results are similar to those from a comparable experiment in the Bahamas (western Atlantic), suggesting that priority effects may be a generally important cause of temporal and spatial variability in the composition of reef fish communities.
\end{abstract}

Key words: community dynamics; competition; predation; recruitment; settlement.

\section{INTRODUCTION}

Understanding mechanisms underlying spatial and temporal variability in community structure is a central pursuit in ecology. In demographically open systems (e.g., most marine communities) where juveniles are largely derived from external sources (Connolly and Roughgarden 1999), variability in reproductive output, larval survival, and dispersal can result in a seemingly unpredictable assemblage of species (review by Morgan 2001). However, if community residents influence colonization in taxon-specific ways, understanding such interactions can provide insight into mechanisms generating compositional differences between, and changes within, communities. Such effects have been documented in a variety of systems (Sousa 1979, Wilbur and Alford 1985, Bertness and Shumway 1993, Almany 2003) and introduce a level of determinism and predictability to community dynamics.

Coral reef fish communities rely on a spatially and temporally unpredictable supply of planktonic larvae for colonizing juveniles (review by Sale 1991). Larvae typically make a nocturnal transition to reef habitats in a process called settlement (Leis 1991, Victor 1991), and the net process of settlement and early post-settlement mortality is called recruitment. Although some

Manuscript received 17 November 2003; revised 3 March 2004; accepted 16 March 2004; final version received 16 April 2004. Corresponding Editor: J. T. Wootton.

${ }^{1}$ Present address: School of Marine Biology and Aquaculture, James Cook University, Townsville, Queensland 4811 Australia. E-mail: Glenn.Almany@jcu.edu.au have argued that stochastic larval supply is the dominant factor structuring these communities (Sale 1980, Sale and Douglas 1984, Sale et al. 1994), there is some evidence for deterministic settlement. For example, some larvae select particular small-scale habitats (Booth 1992, Ohman et al. 1998) or large-scale reef zones (reviews by Williams 1991, Booth and Wellington 1998) in which to settle. However, we know relatively little about the processes underlying changes in community composition within habitats.

After settlement, competition and predation between newly settled fishes (recruits) and established residents may influence community composition. Growing evidence suggests that such interactions can rapidly and substantially modify patterns established by larval supply (Webster 2002, Webster and Almany 2002, Almany 2003). For example, prior residency by competitors and predators can both inhibit and enhance recruitment of conspecifics and heterospecifics (Shulman et al. 1983, Sweatman 1985, Booth 1992, Almany 2003). When residents influence recruitment in taxon-specific ways, the recruitment history of a community can influence its future composition by setting the stage for interactions between residents and recruits. However, we know relatively little about whether interactions between different types of residents modify such priority effects.

Research on coral reef fishes has typically occurred in either the western Pacific or western Atlantic and Caribbean, and comparative studies between the two regions are rare (review by Thresher 1991). The dom- 
inant hypotheses regarding processes structuring reef fish communities are: (1) composition is primarily determined by stochastic larval supply, and (2) composition is primarily determined by post-settlement interactions (reviews by Jones 1991, Thresher 1991). Thresher (1991) and Tupper and Hunt (1998) have argued that most evidence for hypothesis 1 comes from western Pacific studies, while evidence for hypothesis 2 comes from western Atlantic studies, leading to speculation that the primary mechanisms underlying spatial differences and temporal changes in communities differ between regions in fundamental ways. The search for general principles would clearly benefit from conducting similar studies in each system (reviews by Hixon 1991, Jones 1991).

This paper reports on a study conducted on the Great Barrier Reef that replicated a study in the Bahamas (Almany 2003). As in the Bahamian study, I factorially manipulated prior residency by predators and potential competitors and addressed three questions: (1) do predators and competitors affect recruitment and recruit mortality, (2) how quickly are recruitment patterns established, and (3) how similar are effects of residents between studies? I predicted that predators and competitors would negatively influence recruitment and survival of all species, that patterns would be established within a few days of settlement, and that, qualitatively, resident effects would be similar to those observed in the Bahamas.

\section{Methods \\ Study site}

This study took place during the 1999-2000 austral summer at Lizard Island on the northern Great Barrier Reef, Australia $\left(14^{\circ} 40^{\prime} \mathrm{S}, 145^{\circ} 28^{\prime} \mathrm{E}\right)$. In 1993 researchers consolidated live patches of a single coral species (Porites cylindrica) into an array of reefs on the bottom of the lagoon (M. A. Hixon and G. P. Jones, personal communication). Reefs had been unmanipulated for three years prior to this experiment. On average, reefs were $3.2 \mathrm{~m}$ long $(1 \mathrm{SE}=0.05 \mathrm{~m})$ by 0.6 $\mathrm{m}$ wide $(0.01 \mathrm{~m})$ with a surface area of $2.0 \mathrm{~m}^{2}(0.05$ $\mathrm{m}^{2}$ ). Reefs were separated from each other and the main reef by $30 \mathrm{~m}$ of sand. Because similar isolation distance inhibits between-reef movements of small fishes (Doherty 1982, Hixon and Beets 1989), the disappearance of a newly settled recruit was attributed to mortality.

\section{Study species}

I factorially manipulated the presence of two resident groups, piscivores and damselfishes. Piscivores consisted of two species, Cephalopholis boenak (Serranidae) and Pseudochromis fuscus (Pseudochromidae), which prey on juvenile fishes (Blaber et al. 1990, Beukers and Jones 1997). All piscivores were $\leq 10 \mathrm{~cm}$ total length (TL). Damselfish (Pomacentridae) consisted of six species: the planktivore Neopomacentrus cyano- mos, and the omnivores Dascyllus aruanus, Pomacentrus amboinensis, P. moluccensis, P. nagasakiensis, and $P$. pavo (Allen 1991). All damselfish were $\geq 3.5$ cm TL.

\section{Experimental design}

I factorially manipulated the presence and absence of piscivores and damselfish on 20 reefs. To minimize confounding effects of variable larval supply, I selected five blocks of reefs, each block containing four reefs, such that reefs within a block were close to each other. Blocks were arranged with respect to the direction of the incoming tidal current. Within blocks, I randomly assigned reefs to four treatments: (1) piscivores and damselfish present $(\mathrm{P}+\mathrm{D}+)$, (2) piscivores present, damselfish removed $(\mathrm{P}+\mathrm{D}-)$, (3) piscivores removed, damselfish present $(\mathrm{P}-\mathrm{D}+)$, and (4) piscivores and damselfish removed $(\mathrm{P}-\mathrm{D}-)$. On $\mathrm{P}+$ reefs, I standardized piscivore abundance (via removals and additions) to 4-6 C. boenak and 1-2 P. fuscus per reef, which was between the mean $(3.0 C$. boenak and 1.7 $P$. fuscus) and the maximum ( 9 C. boenak and $3 P$. fuscus) initial density. On D + reefs, I standardized damselfish abundance to $\sim 80$ individuals (the lowest density observed prior to manipulations), and relative abundance to the premanipulation mean: $\sim 28 \mathrm{~N}$. $\mathrm{cy}$ anomos, 24 P. amboinensis, 12 P. nagasakiensis, eight $P$. pavo, four P. moluccensis, and four D. aruanus. All other species were removed. Fish manipulations were conducted using clove oil as an anesthetic (Munday and Wilson 1997), hand nets, and a BINCKE (benthic ichthyofauna net for coral/kelp environments) net (Anderson and Carr 1998).

After establishing treatments, I removed all existing recruits. Thereafter, I censused each reef every $48 \mathrm{~h}$ for 50 days. During censuses, I noted (1) fish that had settled since the previous census (identified by small size, incomplete pigmentation, and location), (2) previously recorded recruits, and (3) disappearances. Locations of newly settled fishes were marked with flagging tape. Species that settle at small sizes (e.g., damselfishes) were the most numerous, and the sedentary nature of these species for several weeks post-settlement allowed for identification of individuals. Species that settle at larger sizes and are more mobile were relatively rare, which permitted identification of individuals. During censuses, I counted piscivores on $\mathrm{P}+$ reefs and removed any immigrant piscivores (on $\mathrm{P}-$ reefs) and damselfish (on D - reefs). Immigration during the study was low (16 C. boenak, three P. fuscus, and 16 damselfish). The number of piscivores on each reef remained constant throughout the study and no piscivore recruitment was observed.

\section{Data analysis}

I limited analyses to recruits that were conspicuous and could be reliably censused. These included damselfish, butterflyfish (Chaetodontidae), surgeonfish 
TABLE 1. Total number of new settlers observed during the 50-day experiment and total number of recruits present on the last day of the experiment on each treatment.

\begin{tabular}{|c|c|c|c|c|c|c|c|c|}
\hline \multirow[b]{2}{*}{ Family } & \multicolumn{4}{|c|}{ Total new settlers per treatment $\dagger(1 \mathrm{SE})$} & \multicolumn{4}{|c|}{ Total recruit abundance on day 50 (1 SE) } \\
\hline & $\mathrm{P}+\mathrm{D}+$ & $\mathrm{P}+\mathrm{D}-$ & $\mathrm{P}-\mathrm{D}+$ & $\mathrm{P}-\mathrm{D}-$ & $\mathrm{P}+\mathrm{D}+$ & $\mathrm{P}+\mathrm{D}-$ & $\mathrm{P}-\mathrm{D}+$ & $\mathrm{P}-\mathrm{D}-$ \\
\hline Damselfish (Pomacentridae) $\ddagger$ & $63(1.9)$ & $73(2.9)$ & $180(1.5)$ & $282(2.9)$ & $16(0.6)$ & $15(0.7)$ & $129(3.1)$ & $200(3.2)$ \\
\hline Neopomacentrus cyanomos & $49(5.4)$ & $28(2.9)$ & $66(5.9)$ & $51(4.0)$ & $22(2.6)$ & $21(2.6)$ & $46(5.3)$ & $23(2.7)$ \\
\hline Butterflyfish (Chaetodontidae) & $1(0.2)$ & $1(0.2)$ & $38(1.0)$ & $47(0.9)$ & 0 & 0 & $24(0.6)$ & $33(0.8)$ \\
\hline Surgeonfish (Acanthuridae) & $8(1.6)$ & $3(0.2)$ & $33(1.4)$ & $36(1.0)$ & $3(0.6)$ & $1(0.2)$ & $18(1.2)$ & $27(1.0)$ \\
\hline Rabbitfish (Siganidae) & 0 & 0 & $11(0.9)$ & $28(1.1)$ & 0 & 0 & $6(0.7)$ & $16(1.2)$ \\
\hline
\end{tabular}

Note: A new settler was defined as a recruit observed within 48 h of settlement. Standard errors are for means of the five reefs in that treatment.

$\dagger$ Treatments consisted of the presence $(+)$ or absence $(-)$ of piscivores $(P)$ and damselfishes (D). There were five reefs in each treatment.

$\ddagger$ Neopomacentrus cyanomos was analyzed separately from other damselfish due to differences in behavior (see Methods: Data analysis).

(Acanthuridae), and rabbitfish (Siganidae). Of all recruits observed during the study, $98 \%$ were from these four families. I analyzed differences among treatments at the family level. Such analyses assume that each species within the family responded similarly to manipulations. Within each family recruits were of similar size, trophic status, and appeared to use the reef in similar ways, suggesting that this assumption was reasonable. Two exceptions were the damselfishes $N$. $c y$ anomos and Chromis viridis; recruits of these species remained well above the reef rather than within the coral, as was typical of all other species. Because another study at Lizard Island demonstrated that the demography of $N$. cyanomos differs from that of more reef-associated damselfishes (Webster 2002), I analyzed $N$. cyanomos separately. Recruitment of $C$. viridis was low ( $n=3$ recruits) and therefore excluded from all analyses.

I compared differences in settlement (number of new settlers observed during the 50-d study), recruitment (recruit abundance on the last day of the study), and mortality ([total disappearances/total new settlers] during the study) with ANOVA. The full model included six terms: Block (random effect, five levels), Piscivore (fixed effect, two levels), Damselfish (fixed effect, two levels), and the interactions Piscivore $\times$ Damselfish, Block $\times$ Piscivore, and Block $\times$ Damselfish. In each analysis, there was no evidence for Block $\times$ Piscivore and Block $\times$ Damselfish interactions $(\alpha=0.05)$. I therefore pooled these interactions and evaluated the reduced model. Where the Piscivore $\times$ Damselfish interaction was significant $(P \leq 0.05)$, I provide an estimate and corresponding $95 \%$ confidence interval (95\% CI) for each main effect at both levels of the other main effect, derived from the linear model (Ramsey and Schafer 1997). When the Piscivore $\times$ Damselfish interaction was not significant $(P>0.05)$, I pooled this interaction and analyzed the additive model to estimate effect size and corresponding $95 \%$ CI. I tested variance homogeneity using Levene's $F$ test. Where transfor- mation was required, effect sizes and 95\% CIs were back-calculated from transformed estimates. Error bars in graphs were calculated from untransformed data. I used SAS Institute statistical software JMP version 4.0 (SAS Institute 2000).

\section{RESUlts}

\section{Settlement and recruitment}

Damselfish.-Twelve species settled and $71 \%$ of all individuals were from two species: Pomacentrus amboinensis and $P$. nagasakiensis. There was an interactive effect of piscivores and damselfish on settlement (Table 1; Appendix A). In the absence of damselfish, piscivores reduced settlement by an average (mean and $95 \% \mathrm{CI})$ of $74.7 \pm 14.6 \%$ (42.0 \pm 8.2 settlers $)$, and in the presence of damselfish, piscivores reduced settlement by $42.0 \pm 14.6 \%(23.6 \pm 8.2$ settlers $)$. In the absence of piscivores, damselfish reduced settlement by $35.2 \pm 14.6 \%$ (19.8 \pm 8.2 settlers), but had no effect where piscivores were present. Similarly, there was an interactive effect of piscivores and damselfish on recruitment (Fig. 1A; Appendix B). In the absence of damselfish, piscivores reduced recruitment by $92.5 \pm$ $15.5 \%$ (37.0 \pm 6.2 recruits), and where damselfish were present, piscivores reduced recruitment by $56.5 \pm$ $15.5 \%$ (22.6 \pm 6.2 recruits). In the absence of piscivores, damselfish reduced recruitment by $35.5 \pm 15.5 \%$ (14.2 \pm 6.2 recruits), but had no effect where piscivores were present. I analyzed $N$. cyanomos separately because its behavior differed markedly from other species. For N. cyanomos, both settlement (Table 1; Appendix A) and recruitment (Fig. 1B; Appendix B) were independent of piscivores and damselfish.

Butterflyfish, surgeonfish, and rabbitfish.-Six butterflyfish species settled and $88 \%$ of all individuals were from two species: Chaetodon ephippium and $C$. auriga. A single, unidentifiable surgeonfish species settled. Settlement of butterflyfish and surgeonfish (Table 1) was influenced by piscivores, but not damselfish (Appendix A). Piscivores reduced butterflyfish settle- 

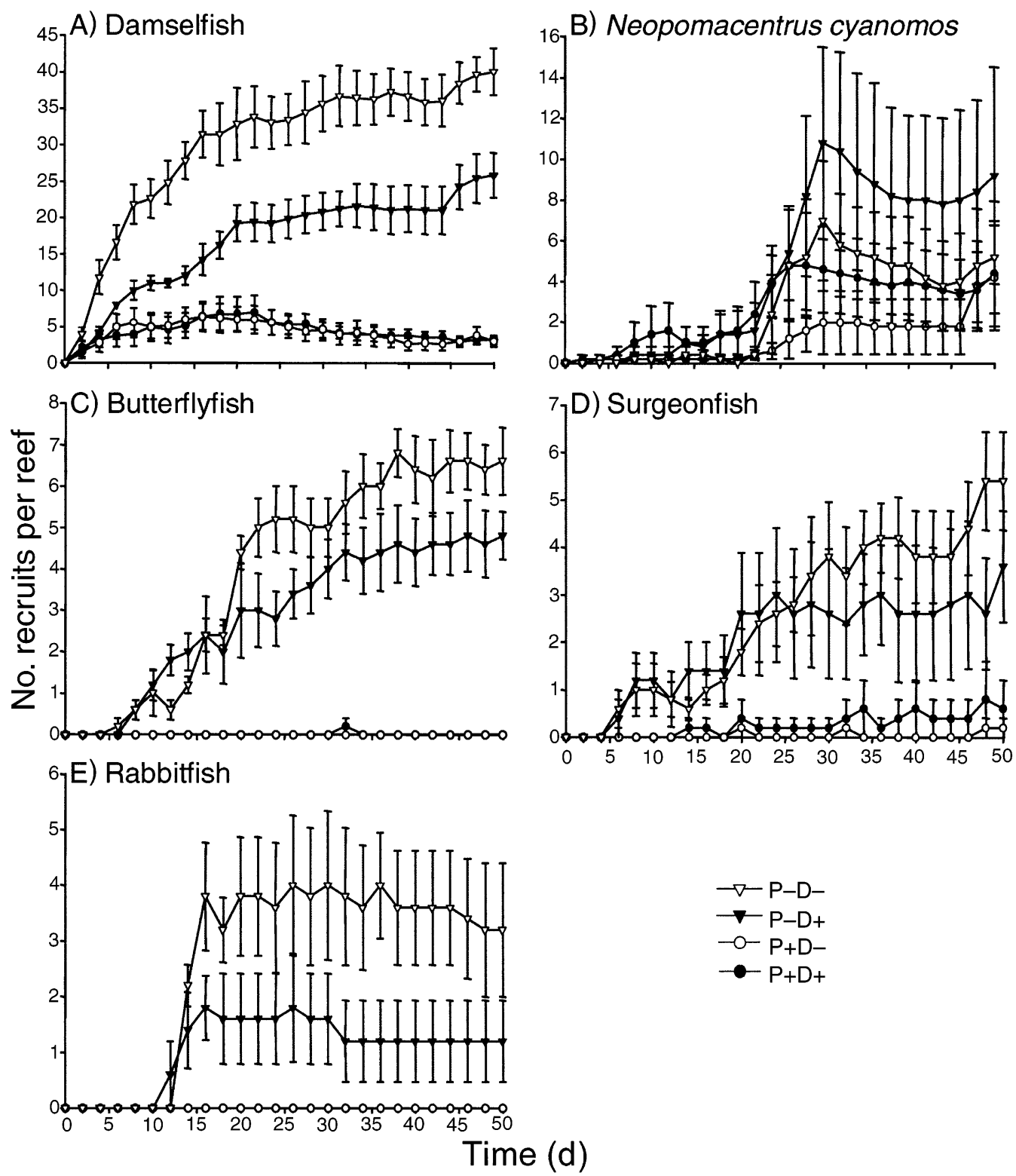

FIG. 1. Differential effects of prior residents on recruitment. The figure shows the relationship between cumulative recruitment (larval settlement minus mortality) and experimental treatments ( $n=4$ reefs each) for (A) all damselfish species, excluding Neopomacentrus cyanomos, (B) N. cyanomos (Pomacentridae), (C) butterflyfish (Chaetodontidae), (D) surgeonfish (Acanthuridae), and (E) rabbitfish (Siganidae). Treatments consisted of factorial combinations of the presence $(+)$ and absence $(-)$ of resident piscivores $(\mathrm{P})$ and damselfishes (D). Error bars represent \pm 1 SE. Note that the $y$-axis scale varies among plots.

ment by $85.4 \%$ (95\% CL: $61.0-118.3 \%$ ) (7.0 settlers, 95\% CL: 5.0-9.7), and surgeonfish settlement by 84.1 $\pm 36.2 \%$ (5.8 \pm 2.5 settlers). Similarly, recruitment of butterflyfish (Fig. 1C) and surgeonfish (Fig. 1D) was influenced by piscivores, but not damselfish (Appendix B). Piscivores reduced butterflyfish recruitment by $100.0 \pm 21.1 \%(5.7 \pm 1.2$ recruits $)$ and surgeonfish recruitment by $91.1 \pm 42.2 \%(4.1 \pm 1.9$ recruits $)$. Rabbitfish settlement consisted of two equally abundant species, Siganus doliatus and $S$. corallinus, and there was an interactive effect of piscivores and damselfish (Appendix A); settlement was nil where piscivores were present (Table 1) and in the absence of piscivores, damselfish reduced settlement by $60.7 \pm 41.1 \%$ (3.4 \pm 2.3 settlers). Rabbitfish recruitment was influenced only by piscivores (Fig. 1E; Appendix B), which reduced recruitment by $100.0 \pm 68.2 \%(2.2 \pm 1.5$ recruits). 


\section{Mortality}

Damselfish.-Mortality differed among blocks and was influenced by piscivores, but not damselfish (Appendix C). Piscivores increased mortality by $46.1 \pm$ $8.0 \%$. Mean percentage mortality ( $1 \mathrm{SE}$ ) among the five blocks was: block $1=45.4 \%$ (12.0), block $2=44.7 \%$ (15.3), block $3=59.2 \%$ (13.1), block $4=66.0 \%$ (13.8), and block $5=45.6 \%$ (14.8). For N. cyanomos, mortality was independent of both piscivores and damselfish (Appendix C).

Butterflyfish, surgeonfish, and rabbitfish.-Settlement of these families was low where piscivores were present (Table 1), preventing mortality comparisons among the four treatments. Where piscivores had been removed, damselfish did not influence mortality ( $\mathrm{P}-\mathrm{D}-$ vs. $\mathrm{P}-\mathrm{D}+t$ test: butterflyfish, $P=0.103$; surgeonfish, $P=0.497$; rabbitfish, $P=0.399)$.

\section{Discussion}

Priority effects occur when residents influence which species enter the community and/or affect their relative abundance. Such effects appear to be common in ecological systems and reveal an important mechanism by which community composition changes through time or varies in space. In demographically open systems such as assemblages of coral reef fishes, a frequent explanation for observed variability in community structure over relatively small spatial and temporal scales is that larval supply is spatially and temporally variable (e.g., Sale and Douglas 1984, Gaines and Roughgarden 1985, Sale et al. 1994). However, as this study demonstrates, variability in community composition can also arise due to taxon-specific interactions between residents and newly arrived colonizers.

In the present study, resident piscivores reduced settlement (recruits observed within $48 \mathrm{~h}$ of settlement) of butterflyfish, surgeonfish, rabbitfish, and most damselfish, and increased mortality of damselfish recruits. Low settlement and high subsequent mortality resulted in low recruitment (final abundance) on reefs with piscivores. At the most extreme, piscivores prevented recruitment of butterflyfish and rabbitfish. In contrast, resident damselfish only reduced settlement of rabbitfish and damselfish and did not affect mortality. Only damselfish recruitment was reduced by the presence of resident damselfish.

While results demonstrate that piscivores and damselfish influenced subsequent colonization, they do not reveal causative mechanisms. Differences in settlement among treatments (Table 1), which mirror differences in recruitment, suggest two likely mechanisms: (1) larvae settled differentially among treatments, or (2) mortality within $48 \mathrm{~h}$ of settlement differed among treatments. Evidence points to differential mortality as the most likely cause. First, a study testing whether larvae select reefs based on piscivore or damselfish presence found no evidence for differential settlement (Almany
2003). Second, it is unlikely that larvae can reliably detect settlement sites free of predators and competitors during nocturnal settlement because the predators and competitors of settling larvae are taxonomically diverse, ubiquitous, and mobile relative to new settlers, and any nonvisual cues (i.e., chemical or auditory) would be nonspecific and widespread (review by Hixon 1991, Webster 2002, Almany 2003). Finally, in this study, damselfish recruits that survived the first $48 \mathrm{~h}$ post-settlement subsequently suffered higher mortality on piscivore-occupied reefs compared to reefs where piscivores had been removed; such differential mortality between piscivore-occupied and piscivore-free reefs was likely even greater during the first $48 \mathrm{~h}$ after settlement (Hixon and Carr 1997, Schmitt and Holbrook 1999, Planes and Lecaillon 2001, Webster 2002).

Another mechanism by which patterns of abundance could be influenced is the movement of recruits among reefs. I assumed that such movements did not occur, but this assumption appears weakest for butterflyfish, surgeonfish, and rabbitfish because recruits from these families settle at relatively large sizes and are at least capable of swimming distances of $30 \mathrm{~m}$ (Stobutzki and Bellwood 1997, Stobutzki 1998). I rarely saw newly settled butterflyfish, surgeonfish, and rabbitfish on piscivore-occupied reefs, which I attributed to early, unobserved mortality. If the absence of these recruits was instead due to post-settlement movements, then such movements must have occurred within $48 \mathrm{~h}$ of settlement. However, in a study that quantified movements between concrete-block reefs of recently settled (within 48 hours of settlement), tagged, and transplanted butterflyfish and surgeonfish recruits, only 1 of 85 butterflyfish and 3 of 87 surgeonfish moved between reefs separated by 20-50 m (Frederick 1997). That even recruits transplanted to artificial reefs appear reluctant to move over these distances supports the assumption that post-settlement movement had little impact on the results of the present study.

The qualitative similarity in settlement and recruitment differences among treatments (Table 1) suggests that patterns were largely established within $48 \mathrm{~h}$ of settlement. Assuming actual settlement was relatively even among treatments, and differences in observed settlement were due to unobserved mortality, it is possible to estimate mortality during the first $48 \mathrm{~h}$ on the reef. For example, 282 newly settled damselfish were observed where piscivores and damselfish had been removed (Table $1, \mathrm{P}-\mathrm{D}-$ reefs), which is an unbiased estimate of actual settlement to the remaining treatments. If true, then $\sim 75 \%$ and $\sim 35 \%$ of all settlers suffered mortality within $48 \mathrm{~h}$ of settlement on reefs with piscivores $(\mathrm{P}+\mathrm{D}-$ and $\mathrm{P}+\mathrm{D}+)$ and only damselfish $(\mathrm{P}-\mathrm{D}+)$, respectively. Furthermore, after $48 \mathrm{~h}$, $\sim 18 \%$ of all settlers suffered mortality on each of the three treatments $(\mathrm{P}+\mathrm{D}+, \mathrm{P}+\mathrm{D}-, \mathrm{P}-\mathrm{D}+)$. Similar calculations for butterflyfish and surgeonfish reveal that $\sim 98 \%$ and $84 \%$, respectively, of settlers suffered mor- 
tality on piscivore-occupied reefs within $48 \mathrm{~h}$ of settlement. These results support both the prediction that patterns of abundance were established rapidly and the conclusions of recent studies of high mortality during the first few days post-settlement (Planes and Lecaillon 2001, Steele and Forrester 2002, Webster 2002, Almany 2003).

While results support the prediction that piscivores would negatively affect most species, resident damselfish reduced only rabbitfish and damselfish settlement and damselfish recruitment, but did not affect mortality. Since mortality estimates were based on following individuals after up to $48 \mathrm{~h}$ on the reef, the lack of an effect on mortality suggests that damselfish effects occurred within $48 \mathrm{~h}$ of settlement, but not after. The most likely mechanism is that damselfish aggression towards recruits made recruits more susceptible to predation from resident and/or transient piscivores (Carr et al. 2002, Almany 2003) perhaps by forcing recruits away from shelter (Holbrook and Schmitt 2002). Why would such effects be confined to the first $48 \mathrm{~h}$ after settlement? I hypothesize that, during the first $48 \mathrm{~h}$ on the reef, recruits gain behavioral attributes (e.g., recognition of competitors and predators, familiarity with the local environment) that allow them to better utilize shelter and minimize negative interactions with residents (see also Almany 2004).

\section{Comparisons with Bahamian reefs}

In a similar study in the Bahamas (Almany 2003), I cross-factored the presence and absence of piscivores and damselfishes on 16 patch reefs and monitored subsequent recruitment for $44 \mathrm{~d}$. Reefs were separated from each other by $200 \mathrm{~m}$ of sand and seagrass and were grouped into four blocks. Each reef consisted of 2 or 3 coral species (Porites asteroids, Montastrea annularis, and Siderastrea siderea). There were five species of piscivores, three groupers (Serranidae: Cephalopholis cruentata, C. fulva, and Epinephelus striatus) and two moray eels (Muraenidae: Gymnothorax moringa and $G$. vicinus). There were two species of damselfish, Stegastes leucostictus and S. partitus.

In the Bahamas, piscivores negatively influenced recruitment of a damselfish and surgeonfish, and positively influenced recruitment of a wrasse (Labridae). In contrast, damselfish negatively influenced recruitment of the damselfish, positively affected recruitment of the surgeonfish, and had no effect on wrasse recruitment. Butterflyfish did not recruit, and rabbitfish are not present in the Bahamas.

There were a number of similarities between the results of the present study and the Bahamian study. First, in both studies recruitment patterns were established rapidly by mortality differences among treatments. Newly settled fish may be subject to especially high mortality if the shift from pelagic to benthic habitats, physiological changes during metamorphosis and small size make them more vulnerable to predation and com- petition. Such transitional periods between life stages are often associated with high mortality in other organisms such as frogs and invertebrates (Arnold and Wassersug 1978, Newell et al. 2000). Second, piscivores at both sites had strong negative effects on damselfish that maintain close contact with the reef, but little effect on those that remained above the reef feeding on passing plankton (Neopomacentrus cyanomos at Lizard Island and Stegastes partitus in the Bahamas). Such less reef-associated species may be more influenced by transient piscivores, such as jacks (Carangidae), which often feed on planktivores above reefs (Hixon and Carr 1997, Webster 2002). Jacks were common in both studies and had free access to all reefs. Finally, piscivores in both studies had strong negative effects on species that both settle at relatively large sizes and were less common (surgeonfish, rabbitfish, and butterflyfish at Lizard Island; surgeonfish in the Bahamas). Piscivores may have disproportionately targeted these species, which are 2-3 times larger at settlement than damselfish, due to their large size (see Rice et al. 1993, Sogard 1997), or perhaps because they differed in appearance and behavior from the majority of recruits (i.e., damselfish) and were thus more visually conspicuous.

One difference between studies was the relative effect of resident damselfish on subsequent damselfish colonization: in the Bahamas, damselfish and piscivores had similar effects, whereas in the present study, damselfish effects were much weaker than piscivore effects. In the Bahamas, resident damselfish consisted of two highly territorial species (Stegastes leucostictus and $S$. partitus), which are relatively more aggressive than the damselfish manipulated in this study (Williams 1980, Robertson 1996). In support of this conclusion, in the Bahamas I frequently observed aggression between adult and juvenile damselfish, which in several cases resulted in visible injury to juveniles (e.g., tattered fins and open wounds), while aggression between adults and juveniles in this study was uncommon and never resulted in visible injury. Greater aggression likely caused higher recruit mortality, either directly or indirectly, which could explain the greater effects of Bahamian damselfish.

Another notable difference between studies was that piscivores and damselfish in the Bahamas had positive effects on the recruitment of some species, whereas no such positive effects were detected in the present study. In the Bahamas, piscivores enhanced recruitment of the bluehead wrasse, Thalassoma bifasciatum. Juvenile $T$. bifasciatum are facultative cleaners that remove, and consume, ectoparasites from other fishes (Itzkowitz 1979). As a result, they may have had access to a greater food supply on reefs with piscivores, thereby enhancing their survival. Furthermore, mortality of $T$. bifasciatum recruits was likely lower than most other species since cleaners typically experience lower predation (Carr and Hixon 1995, Poulin and Vickery 
1995). No species known to engage in cleaning behavior recruited during the present study. Similarly, Bahamian damselfishes enhanced surgeonfish recruitment on reefs where resident piscivores had been removed. On these reefs, the primary source of recruit mortality was likely transient predators, such as jacks. I frequently observed aggressive interactions between damselfish and jacks in the Bahamas, and in other systems surgeonfish and damselfish often share in defense of jointly occupied territories (Robertson and Polunin 1981, Roberts 1985). As a result, juvenile surgeonfish may have obtained antipredator benefits from damselfish aggression. The absence of similar positive effects of damselfish in the present study could therefore be due to their relatively nonaggressive behavior.

\section{Conclusions}

Can results from this study tell us anything about the dynamics of fish communities on larger contiguous reefs? The experimental reefs in this study consisted of a single coral species, whereas contiguous reefs are composed of a variety of coral species, each of which differs in its structural complexity. Because increased complexity may reduce predation and/or competition by providing more refuges (MacArthur and Levins 1967, Murdoch and Oaten 1975), the variability in complexity on contiguous reefs could influence the strength of the priority effects documented in this study. However, in the only study to manipulate both the structural complexity of live-coral reefs and the presence of predators and competitors, I found that effects of residents on settlement and early recruit mortality were similar among habitat complexity treatments (Almany 2004, in press). More generally, contiguous reefs are inherently patchy environments because many reef fishes occupy distinct home ranges (e.g., Kramer and Chapman 1999). As a result, contiguous reefs represent a conglomeration of patches, each with its own occupants. For example, predators such as Cephalopholis boenak typically remain in relatively small, well-defined areas on large contiguous reefs (Stewart and Jones 2001), which results in a mosaic of predation risk based on the locations of predator home ranges. Similar well-defined home ranges are occupied by many damselfishes (Allen 1991). Even in spatially continuous environments, such behavior can lead to the development of dynamic patchiness (Levin 1974). As a result, patch reef studies may indeed be useful for understanding community dynamics on large contiguous reefs.

The dynamics of open communities clearly depend on both the input and subsequent loss of colonizers. Understanding the causes of spatial differences among, and temporal changes within, these communities remains a formidable challenge, but is greatly facilitated by identifying general principles. Results from this study and a comparable study in the Bahamas were remarkably similar, suggesting that similar mechanisms underlie these effects. Priority effects in both studies were strong, taxon-specific, and resulted in dramatically different communities of recruits after approximately seven weeks. Such differences were likely reflected in the subsequent structure of these communities because mortality typically declines dramatically after the first few weeks post-settlement (review by Hixon and Webster 2002), although long-term monitoring would be necessary to determine to what extent this was true. Finally, the similarities between the two studies suggests that priority effects are a central feature of coral reef fish communities (see also Shulman et al. 1983). This last conclusion seems especially warranted given that the two studies were conducted in systems that essentially represent opposite ends of the global spectrum of coral reef ecosystems. In general, western Atlantic coral reefs support far fewer coral and fish species than Indo-Pacific reefs (Thresher 1991), and Bahamian reefs are less diverse than most western Atlantic sites, perhaps because the Bahamas are primarily subtropical and highly seasonal (Bohlke and Chaplin 1993). In contrast, the northern Great Barrier Reef is tropical, relatively nonseasonal, and highly diverse. This study is one of the first to demonstrate that, despite substantial differences between the two regions, their fish communities share important dynamic features.

\section{ACKNOWLEDGMENTS}

I thank M. Webster and T. Freidenburg for field assistance, M. Hixon and G. Jones for use of experimental reefs, and the staff of Lizard Island Research Station. A National Science Foundation (USA) Graduate Predoctoral Fellowship and International Research Fellowship, a Fulbright Postgraduate Award, and National Science Foundation (USA) grants (OCE-96-17483 and OCE-00-93976) to M. Hixon provided financial support. For advice and reviews, I thank my graduate committee: M. Hixon (chair), P. Bayley, M. Carr, B. Menge, and S. Sogard. Additional reviews were provided by M. McCormick, P. Munday, K. Overholtzer, G. Jones, and M. Webster.

\section{Literature Cited}

Allen, G. R. 1991. Damselfishes of the world. Mergus, Melle, Germany.

Almany, G. R. 2003. Priority effects in coral reef fish communities. Ecology 84:1920-1935.

Almany, G. R. 2004. Does increased habitat complexity reduce predation and competition in coral reef fish assemblages? Oikos 106:275-284.

Almany, G. R. In press. Differential effects of habitat complexity, predators and competitors on abundance of juvenile and adult coral reef fishes. Oecologia.

Anderson, T. W., and M. H. Carr. 1998. BINCKE: a highly efficient net for collecting reef fishes. Environmental Biology of Fishes 51:111-115.

Arnold, S. J., and R. J. Wassersug. 1978. Differential predation on metamorphic anurans by garter snakes (Thamnophis): social behavior as a possible defense. Ecology 59: 1014-1022.

Bertness, M. D., and S. W. Shumway. 1993. Competition and facilitation in marsh plants. American Naturalist 142:718724. 
Beukers, J. S., and G. P. Jones. 1997. Habitat complexity modifies the impact of piscivores on a coral reef fish population. Oecologia 114:50-59.

Blaber, S. J. M., D. A. Milton, N. J. F. Rawlinson, G. Tiroba, and P. V. Nichols. 1990. Diets of lagoon fishes of the Solomon Islands: predators of tuna baitfish and trophic effects of baitfishing on the subsistence fishery. Fisheries Research 8:263-286.

Bohlke, J. E., and C. C. G. Chaplin. 1993. Fishes of the Bahamas and adjacent territorial waters. Second edition. University of Texas Press, Austin, Texas, USA.

Booth, D. J. 1992. Larval settlement patterns and preferences by domino damselfish Dascyllus albisella Gill. Journal of Experimental Marine Biology and Ecology 155:85-104.

Booth, D. J., and G. Wellington. 1998. Settlement preferences in coral-reef fishes: effects on patterns of adult and juvenile distributions, individual fitness and population structure. Australian Journal of Ecology 23:274-279.

Carr, M. H., T. W. Anderson, and M. A. Hixon. 2002. Biodiversity, population regulation, and the stability of coralreef fish communities. Proceedings of the National Academy of Sciences (USA) 99:11241-11245.

Carr, M. H., and M. A. Hixon. 1995. Predation effects on early post-settlement survivorship of coral-reef fishes. Marine Ecology Progress Series 124:31-42.

Connolly, S. R., and J. Roughgarden. 1999. Theory of marine communities: competition, predation, and recruitment-dependent interaction strength. Ecological Monographs 69: 277-296.

Doherty, P. J. 1982. Some effects of density on the juveniles of two species of tropical, territorial damselfishes. Journal of Experimental Marine Biology and Ecology 65:249-261.

Frederick, J. L. 1997. Post-settlement movement of coral reef fishes and bias in survival estimates. Marine Ecology Progress Series 150:65-74.

Gaines, S., and J. Roughgarden. 1985. Larval settlement rate a leading determinant of structure in an ecological community of the marine intertidal zone. Proceedings of the National Academy of Sciences (USA) 82:3707-3711.

Hixon, M. A. 1991. Predation as a process structuring coral reef fish communities. Pages 475-508 in P. F. Sale, editor. The ecology of fishes on coral reefs. Academic Press, San Diego, California, USA.

Hixon, M. A., and J. P. Beets. 1989. Shelter characteristics and Caribbean fish assemblages: experiments with artificial reefs. Bulletin of Marine Science 44:666-680.

Hixon, M. A., and M. H. Carr. 1997. Synergistic predation, density dependence, and population regulation in marine fish. Science 277:946-949.

Hixon, M. A., and M. S. Webster. 2002. Density dependence in reef fish populations. Pages 303-325 in P. F. Sale, editor. Coral reef fishes: dynamics and diversity in a complex ecosystem. Academic Press, San Diego, California, USA.

Holbrook, S. J., and R. J. Schmitt. 2002. Competition for shelter space causes density-dependent predation mortality in damselfishes. Ecology 83:2855-2868.

Itzkowitz, M. 1979. The feeding strategies of a facultative cleanerfish, Thalassoma bifasciatum (Pisces: Labridae). Journal of Zoology 187:403-413.

Jones, G. P. 1991. Postrecruitment processes in the ecology of coral reef fish populations: a multifactorial perspective. Pages 294-328 in P. F. Sale, editor. The ecology of fishes on coral reefs. Academic Press, San Diego, California, USA.

Kramer, D. L., and M. R. Chapman. 1999. Implications of fish home range size and relocation for marine reserve function. Environmental Biology of Fishes 55:65-79.

Leis, J. M. 1991. The pelagic stage of reef fishes: the larval biology of coral reef fishes. Pages 183-230 in P. F. Sale, editor. The ecology of fishes on coral reefs. Academic Press, San Diego, California, USA.

Levin, S. A. 1974. Dispersion and population interaction. American Naturalist 108:207-228.

MacArthur, R. H., and R. Levins. 1967. The limiting similarity, convergence, and divergence of coexisting species. American Naturalist 101:377-385.

Morgan, S. G. 2001. The larval ecology of marine communities. Pages 159-181 in M. D. Bertness, S. D. Gaines, and M. E. Hay, editors. Marine community ecology. Sinauer Associates, Sunderland, Massachusetts, USA.

Munday, P. L., and S. K. Wilson. 1997. Comparative efficacy of clove oil and other chemicals in anaesthetization of $\mathrm{Po}$ macentrus amboinensis, a coral reef fish. Journal of Fish Biology 51:931-938.

Murdoch, W. W., and A. Oaten. 1975. Predation and population stability. Advances in Ecological Research 9:1-132.

Newell, R. I. E., G. S. Alspach, Jr., V. S. Kennedy, and D. Jacobs. 2000. Mortality of newly metamorphosed eastern oysters (Crassostrea virginica) in mesohaline Chesapeake Bay. Marine Biology 136:665-676.

Ohman, M. C., P. L. Munday, G. P. Jones, and M. J. Caley. 1998. Settlement strategies and distribution patterns of coral-reef fishes. Journal of Experimental Marine Biology and Ecology 225:219-238.

Planes, S., and G. Lecaillon. 2001. Caging experiment to examine mortality during metamorphosis of coral reef fish larvae. Coral Reefs 20:211-218.

Poulin, R., and W. L. Vickery. 1995. Cleaning symbiosis as an evolutionary game: to cheat or not to cheat? Journal of Theoretical Biology 175:63-70.

Ramsey, F. L., and D. W. Schafer. 1997. The statistical sleuth: a course in methods of data analysis. Duxbury Press, Belmont, California, USA.

Rice, J. A., L. B. Crowder, and K. A. Rose. 1993. Interactions between size-structured predator and prey populations: experimental test and model comparison. Transactions of the American Fisheries Society 122:481-491.

Roberts, C. M. 1985. Resource sharing in territorial herbivorous reef fishes. Proceedings of the Fifth International Coral Reef Congress 4:17-22.

Robertson, D. R. 1996. Interspecific competition controls abundance and habitat use of territorial Caribbean damselfishes. Ecology 77:885-899.

Robertson, D. R., and V. C. Polunin. 1981. Coexistence: symbiotic sharing of feeding territories and algal food by some coral reef fishes from the western Indian Ocean. Marine Biology 62:185-195.

Sale, P. F. 1980. Assemblages of fish on patch reefs-predictable or unpredictable? Environmental Biology of Fishes 5:243-249.

Sale, P. F. 1991. Introduction. Pages 3-15 in P. F. Sale, editor. The ecology of fishes on coral reefs. Academic Press, San Diego, California, USA.

Sale, P. F., and W. A. Douglas. 1984. Temporal variability in the community structure of fish on coral patch reefs and the relation of community structure to reef structure. Ecology 65:409-422.

Sale, P. F., J. A. Guy, and W. J. Steel. 1994. Ecological structure of assemblages of coral reef fishes on isolated patch reefs. Oecologia 98:83-99.

SAS Institute. 2000. JMP user's guide, version 4. SAS Institute, Cary, North Carolina, USA.

Schmitt, R. J., and S. J. Holbrook. 1999. Mortality of juvenile damselfish: implications for assessing processes that determine abundance. Ecology 80:35-50.

Shulman, M. J., J. C. Ogden, J. P. Ebersole, W. N. Mcfarland, S. L. Miller, and N. G. Wolf. 1983. Priority effects in the recruitment of juvenile coral reef fishes. Ecology 64:15081513. 
Sogard, S. M. 1997. Size-selective mortality in the juvenile stage of a teleost fish: a review. Bulletin of Marine Science 60: $1129-1157$

Sousa, W. P. 1979. Disturbance in marine intertidal boulder fields: the nonequilibrium maintenance of species diversity. Ecology 60:1225-1239.

Steele, M. A., and G. E. Forrester. 2002. Early postsettlement predation on three reef fishes: effects on spatial patterns of recruitment. Ecology 83:1076-1091.

Stewart, B. D., and G. P. Jones. 2001. Associations between the abundance of piscivorous fishes and their prey on coral reefs: implications for prey-fish mortality. Marine Biology 138:383-397.

Stobutzki, I. C. 1998. Interspecific variation in sustained swimming ability of late pelagic stage reef fish from two families (Pomacentridae and Chaetodontidae). Coral Reefs 17:111-119.

Stobutzki, I. C., and D. R. Bellwood. 1997. Sustained swimming abilities of the late pelagic stages of coral reef fishes. Marine Ecology Progress Series 149:35-41.

Sweatman, H. P. A. 1985. The influence of adults of some coral reef fishes on larval recruitment. Ecological Monographs 55:469-485.

Thresher, R. E. 1991. Geographic variability in the ecology of coral reef fishes: evidence, evolution, and possible im- plications. Pages 401-436 in P. F. Sale, editor. The ecology of fishes on coral reefs. Academic Press, San Diego, California, USA.

Tupper, M., and W. Hunte. 1998. Predictability of fish assemblages on artificial and natural reefs in Barbados. Bulletin of Marine Science 62:919-935.

Victor, B. C. 1991. Settlement strategies and biogeography of reef fishes. Pages 231-260 in P. F. Sale, editor. The ecology of fishes on coral reefs. Academic Press, San Diego, California, USA.

Webster, M. S. 2002. Role of predators in the early postsettlement demography of coral-reef fishes. Oecologia 131 $52-60$.

Webster, M. S., and G. R. Almany. 2002. Positive indirect effects in a coral reef fish community. Ecology Letters 5: 549-557.

Wilbur, H. M., and R. A. Alford. 1985. Priority effects in experimental pond communities: responses of Hyla to Bufo and Rana. Ecology 66:1106-1114.

Williams, D. M. 1980. Dynamics of the pomacentrid community on small patch reefs in One Tree Lagoon (Great Barrier Reef). Bulletin of Marine Science 30:159-170.

Williams, D. M. 1991. Patterns and process in the distribution of coral reef fishes. Pages 437-474 in P. F. Sale, editor. The ecology of fishes on coral reefs. Academic Press, San Diego, California, USA.

\section{APPENDIX A}

ANOVAs comparing the number of new settlers observed on each treatment during the experiment are available in ESA's Electronic Data Archive: Ecological Archives E085-092-A1.

\section{APPENDIX B}

ANOVAs comparing recruit abundance among treatments on the last day of the experiment are available in ESA's Electronic Data Archive: Ecological Archives E085-092-A2.

\section{APPENDIX C}

ANOVAs comparing recruit mortality observed on each treatment during the experiment are available in ESA's Electronic Data Archive: Ecological Archives E085-092-A3. 